\title{
The Idea of Healing in A Fortunate Man: The Story of a Country Doctor ${ }^{1}$
}

\section{Talihli Bir Adam: Bir Taşra Doktorunun Öyküsü’nde İyileş(tir)me Düşüncesi}

\author{
M. Ayça VURMAY*
}

\begin{abstract}
A Fortunate Man: The Story of a Country Doctor is an essay and a narrative, illustrated with photographs, which explores the personal story of a country doctor as well as the story of society and humanity. The text discusses the issues of healing and illness, concentrating on the social and human aspects of these concepts. It explores the idea of healing primarily as a social construct. It is observed that the figure of the healer is handled through the examples of the doctor, as well as the master mariner and the storyteller with regard to humanism and social responsibility. Thus, "healing" is a metaphor in Berger's view which signifies empathizing and human responsibility. Storytelling is a central concept in Berger's outlook as Berger believes the storyteller is a healer as s/he rescues the reader from absurdity while the healer/doctor is a storyteller who records the story of his patients, the community. The aim of this article is to investigate the ideas of healing and the figure of the healer in A Fortunate Man, mainly in social and human terms. It is revealed that the value of a healer and the value of society are measured socially.
\end{abstract}

Keywords: Healing, Illness, Storytelling, Humanism, John Berger, Jean Mohr

\section{$\ddot{O} z$}

A Fortunate Man: The Story of a Country Doctor (Talihli Bir Adam: Bir Taşra Doktorunun Öyküsü) taşradaki bir pratisyen doktorun kişisel öyküsünün yanı sıra toplum ve insanlığın öyküsünü irdeleyen, fotoğraflarla bütünlenen bir makale ve anlatıdır. Metinde iyileş(tir)me ve hastalık konuları, bu kavramların toplumsal ve insani yönlerine yoğunlaşarak tartışılır. İyileş(tir)me düşüncesi metinde ağırlıklı olarak toplumsal bir kurgu olarak irdelenir. İyileştirici/sağaltıcı figürünün metinde doktor örneğinin yanı sıra uzman kaptan ve öykü anlatıcısı figürleriyle hümanizma ve toplumsal sorumluluk açısından ele alındığı görülür. Bu nedenle, Berger'in bakış açısına göre "iyileştirme" empati kurma ve insani sorumluluk anlamına gelen bir metafordur. Öykü anlatımı Berger'in düşünce sisteminde merkezi bir yere sahiptir; öyle ki Berger doktorun hastalarının ve toplumun öyküsünü kaydettiği gibi hikayecilerin de okuru anlamsızlıktan kurtardığına inanır. Bu makalenin amacı Talihli Bir Adam'da iyileş(tir)me düşüncesini ve iyileştirici/sağaltıcı figürünü esas olarak toplumsal ve insani açılardan incelemektir. İyileștiricinin değerinin toplumun değeri gibi toplumsal olarak ölçüldüğü ortaya konulur.

Anahtar Kelimeler: İyileştirme, Hastalık, Öykü anlatımı, Hümanizma, John Berger, Jean Mohr

\section{Introduction}

A Fortunate Man: The Story of a Country Doctor (1967) is an essay and a narrative written by John Berger (1926-2017) and illustrated with photographs taken by Jean Mohr (1925-2018). The book is based on their visit to John Sassall, the country doctor in the Forest of Dean. The text has biographical aspects as it records the life story of John Sassall, his medical cases, his thoughts and feelings, his relationship with his patients as well as Berger's assessment of him. It is also a critical one which involves Berger's theories and criticism on contemporary society, which is tied with the idea of universal humanism. The text has literary and fictional aspects as it narrates the story of a country doctor and his patients in a novelistic manner and also consists of references to other writers and literary works in order to make its argument. The idea of healing connects with the idea of humanism in Berger's essay as he thinks the value of a healer can only be assessed through society's assessment of the value of human life. In other words, Berger discusses the value of a healthy society through the metaphor of the story of a country doctor as the doctor represents the value of humanity. In this respect, the text explores the concept of healing mainly as a social and human case. As Bruce

\footnotetext{
${ }^{1}$ This paper is the extended and revised version of the paper entitled "Representations of Healing and Health in A Fortunate Man", orally presented at the "International Başkent Conference: 'Health and Healing in Culture and Literature"" on 13-15 March 2019.

* Dr. Öğretim Üyesi, Hatay Mustafa Kemal Üniversitesi, Fen-Edebiyat Fakültesi, İngiliz Dili ve Edebiyatı Anabilim Dalı, aycavurmay@mku.edu.tr
} 
Robbins states, the concept of humanism, which is central to Berger's vision, connects with Berger's struggle for and contribution to "a new marxist-humanist "commonsense" (Robbins, 1982, p. 293). Robbins further argues that Berger's use of the local peasant experience in his works may function as a metaphor for the idea of a global 'human' universal (Robbins, 1982, p. 292).

Illness in Berger's outlook is not only a personal case but primarily a social one as Berger argues there may be social reasons for the illness of an individual, reflected in community's sickness. To illustrate, Berger refers to the social-historical causes of mental illness and criticizes contemporary society for disregarding this aspect (Berger and Mohr, 2016, p. 145). It discusses the ideas of healing in social terms, through the personal case of a doctor/healer and the author/narrator's diagnoses on social ill(s) as well as his cures. The foremost criteria for a healthy society is the human aspect as the text diagnoses. The book deals with the biography of a country doctor, as well as engaging with social and moral questions. The photographs reflecting the medical and personal cases alternate with the pictures of the country landscape and Berger's essay. To illustrate, the text opens with a series of photographs accompanied by a few statements. The first photograph foregrounds the landscape and emphasizes the idea of the landscape as a social construct rather than mere physical location. The landscape serves as a background and frame for the individual and society as written at the top of the second photograph: "Landscapes can be deceptive. Sometimes a landscape seems to be less a setting for the life of its inhabitants than a curtain behind which their struggles, achievements and accidents take place" (Berger and Mohr, 2016, p. 19). Landscape, thus, is both an agent and a disguise both revealing and concealing the ills, problems, as well as accomplishments and welfare of society. This statement can also be read as an introduction to the doctor's role in society mainly as memory and healer of society, diagnosing the ills, fostering health and providing cures in social as well as medical terms. The second photograph together with the sentence inserted in the middle of the photograph, accentuates the statement in the preceding photo which maintains "For those who, with the inhabitants, are behind the curtain, landmarks are no longer only geographic but also biographical and personal" (Berger and Mohr, 2016, p. 21). From the beginning, the text connects the ideas of health and illness with social landscape, demonstrating that the health of the individuals is determined by the healthiness and diseases of society. It examines the story of a country doctor through medical as well as social landscapes.

The essay also explores the paradoxes, risks and duplicities involved in the idea of healing and the healer, warning against the Faustian dangers of healing at the cost of one's health, since Berger thinks, the doctor's passion for knowledge and the universal is Faustian. As Berger puts it, "Like any Faust without the aid of the devil, he [Sassall] is a man who suffers frequently from a sense of anti-climax", as "[P] art of him is always waiting to know more" (Berger and Mohr, 2016, p. 83). Storytelling is similar to healing in Berger's outlook as the storyteller is a healer who redeems the reader from absurdity, emptiness, futility and catastrophe. Berger mainly focuses on the concepts of empathy, humanism and social responsibility in relation to healing, as he thinks they are common to writers in their service to humanity.

This article will investigate the idea of healing as a multifarious category encompassing medicating, curing, rescuing, sheltering, and empathizing at personal, social and narrative levels in A Fortunate Man: The Story of a Country Doctor. It concerns healing oneself, healing others, as well as healing oneself through healing the other, the social value of healing, universal humanism, and storytelling as healing. The occasion for Berger's writing about Sassall can be traced back to his acquaintance with him as a general practitioner, being treated by him and becoming his friend. Gavin Francis states that Berger and his friend and colleague 
Victor Anant "recognised in Sassall an outstanding physician as well as the enthusiast of an unfashionable ideal - the Renaissance dream of aspiring to universal knowledge and experience" (Francis, 2016, p. 10).

The idea of storytelling is related to the idea of healing and humanism in the text, as the doctor heals society while the storyteller saves humanity. In the conversation between Berger and Susan Sontag entitled "To Tell A Story" (1983), Berger discusses his conception of fiction as "a fight against the absurd," against "that endless, terrifying space in which we live" (Berger and Sontag, 1983). To Berger "A story is always a rescuing operation" (Berger and Sontag, 1983). The storyteller, according to Berger, shelters the reader from the absurd (Berger and Sontag, 1983). Likewise, the doctor rescues the patient from absurdity or the unknown. Berger regards storytellers as "death's secretaries" (Berger and Sontag, 1983). To Berger an essay and a story are similar. Berger emphasizes the role of empathy in writing. He argues that the essay writer like the storyteller relates the "unsayable" and makes it familiar (Berger and Sontag, 1983).

Sassall's role as a doctor is similar to the role Berger assigns to storytellers in that the doctor "witness"es the patients' condition and provides "fraternity": "The doctor is the familiar of death" (Berger and Mohr, 2016, p. 70). The photographs in the opening pages are succeeded by six stories of novelized case studies regarding Sassall's practice as a doctor as well as his social relationships with his patients. The first narrative is the story of a woodman trapped beneath a tree. The attempt by Sassall to save the woodman or the patient is similar to the role of the storyteller who, Berger believes, rescues the reader from absurdity or the unknown. The metaphor of the doctor as a storyteller is reinforced through the story image in the doctor's rescue of the woodman. The narrator refers to the accident as a fictional "story" which is in progress and to be "concluded" by the doctor's treatment: "The man would tell the story many times, and the first would be tonight in the village. But it was not yet a story. The advent of the doctor brought the conclusion much nearer, but the accident was not yet over [...]" (Berger and Mohr, 2016, pp. 23-24).

The photographs, taken by Jean Mohr provide a vivid embodiment of the subject matter, of the individual as well as the social, through close-ups. The photographs and the narrative constitute a unity, complementing one another. Berger's emphasis on the necessity for a fraternal relationship between the doctor and the patient, for instance, is accompanied by a series of photographs depicting Sassall's relationship with his patients (Berger and Mohr, 2016, pp. 71-75). The subsequent five photographs depicting Sassall's examination of an aged woman through close-ups, illustrate the doctor's fraternity towards his patients, where the shift in the gestures and mimics of the patient during her conversation with Sassall, the woman's fraternity towards her doctor, in particular, can be observed (Berger and Mohr, 2016, pp. 71-73). The succeeding photograph portrays Sassall's examination of a pregnant woman, which foregrounds the patient's mimics which exhibit her trust in her doctor as well as Sassall's fraternity (Berger and Mohr, 2016, p. 74). The choice of the close-up technique accords with the kind of doctor-patient relationship examined in the book, which is a close relationship based on the principle of treating the patient as a whole being, rather than merely as a case of illness. Berger says, Sassall "never separates an illness from the total personality of the patient -in this sense he is the opposite of a specialist. He does not believe in maintaining his imaginative distance: he must come close enough to recognize the patient fully" (Berger and Mohr, 2016, p. 114). The close-up method is not only observed in Sassall's attitude to each patient but in the conception of the text which approaches its object directly by acknowledging it fully. The absence of borders or spaces between the visual and verbal elements, the photographs and the essay/narrative, as well as the absence of explanatory information regard- 
ing the photographs and the lack of chapter divisions and subtitles are in line with the closeup approach. The book provides different versions of the same photograph, which suggests the perception or treatment of each person or object in the picture, from different angles or by coming closer to the object in each picture. Berger's conception of anguish, for instance, is supplemented by five photographs depicting the fraternal relationship between two men, one of whom is sobbing (Berger and Mohr, 2016, pp. 115-120). Through these photographs, which capture different sequences of the same scene, the text foregrounds human suffering and fraternity.

Illness is regarded as the exhibition of individuality or as integral to the personality of the patient since Berger thinks Sassall conceives of illness as "a form of expression" reflecting the patient's "total personality" (Berger and Mohr, 2016, p. 64), which makes him a good doctor: "He [Sassall] is acknowledged as a good doctor because he meets the deep unformulated expectation of the sick for a sense of fraternity. He recognizes them" (Berger and Mohr, 2016, p. 79). Illness, in Berger's view, can be truly diagnosed through the examination of the physical, psychological, environmental, social, and historical factors affecting the individual. In other words, treatment requires an "intimate, individual recognition of the patient" (Berger and Mohr, 2016, p. 76):

Good general diagnosticians are rare, not because most doctors lack medical knowledge, but because most are incapable of taking in all the possibly relevant facts- emotional, historical, environmental as well as physical. They are searching for specific conditions instead of the truth about a man which may then suggest various conditions. (2016, p. 76)

Berger's conception of illness as "a distorted, fragmentated form of selfconsciousness" which demands "fraternity" to "reaffirm the social content of the invalid's aggravated self-consciousness" (Berger and Mohr, 2016, p. 71) can be related to Virginia Woolf's views on sickness and its value in literature as well. Virginia Woolf, in her essay entitled On Being Ill (1926), deplores the omission and neglect of the subject of illness in literature in that she observes that literature engages with the mind at the cost of the body, and shows the affirmative function of sickness, thereby revealing its centrality to human growth, change and illumination. Woolf highlights the connection between common illness and spiritual/mental health:

Considering how common illness is, how tremendous the spiritual change that it brings, [...] it becomes strange indeed that illness has not taken its place with love, battle, and jealousy among the prime themes of literature. Novels, one would have thought, would have been devoted to influenza; epic poems to typhoid; odes to pneumonia, lyrics to toothache. But no, with a few exceptions- [...] literature does its best to maintain that its concern is with the mind: that the body is a sheet of plain glass through which the soul looks straight and clear, and, save for one or to passions such as desire and greed, is null, negligible and non-existent. On the contrary, the very opposite is true. [...] But of all this daily drama of the body there is no record. People write always about the doings of the mind [...] (Woolf, 2014, p. 32)

The condition of illness, for Woolf, indicates a state of thoughtlessness or recklessness which she likens to that of a criminal, where the relationship between common health and spiritual health is highlighted. As the normal or lawful is associated with the healthy, going against law is sickliness. In other words, health is associated with social restraint and civilization whereas illness is related with candour, senselessness and alienation: "There is, let us confess it (and illness is the great confessional) a childish outspokenness in illness; things are said, truths blurted out, which the cautious respectability of health conceals" (Woolf, 2014, p. 36). Woolf further considers illness to be a freedom and richness of expression or creativity as it incites incomprehensibility and metaphorical meaning, hence words acquire a complex net of meanings: 
In illness words seem to possess a mystic quality. We grasp what is beyond their surface meaning [...] a state of mind which neither words can express nor the reason explain. Incomprehensibility has an enormous power over us in illness, more legitimately perhaps than the upright will allow. In health meaning has encroached upon sound. Our intelligence domineers over our senses. But in illness, with the police off duty [...] if at last we grasp the meaning, it is all the richer for having travelled slowly up with all the bloom upon its wings. $(2014$, p. 41)

Berger's views on the social alienation of the diseased and his perception of death and illness as an absurdity to be remedied by the doctor tally with Susan Sontag's critique of the denunciatory conception of illness in society in Illness as Metaphor (1978) (Sontag, 1978, p. 3). Sontag argues that death and illness are perceived as criminal, absurd, malicious and thereby shunned by society: "Contact with someone afflicted with a disease regarded as a mysterious malevolency inevitably feels like a trespass; worse, like the violation of a taboo. The very names of such diseases are felt to have a magic power" $(1978$, p. 6). Sontag continues, "As death is now an offensively meaningless event, so that disease widely considered a synonym for death is experienced as something to hide" (1978, p. 8).

The role of the healer is also explained through the analogy of the Master Mariner in the text. Berger likens the figure of the doctor to a Master Mariner. The comparison is partly due to Conrad's influence on Dr Sassall. It stems from Berger's views on the affinities between a doctor and a mariner regarding their roles. Berger's image of a doctor is that of a person who values imagination and the ideal of service like the Master Mariner. The doctor faces endless and unknown risks, possibilities and challenges like the Mariner facing the sea. In other words, s/he confronts the unimaginable. Furthermore, the doctor is impelled by the ideal of service to humanity or society, and who is wise and experienced like the sea captain. The consulting room is imagined as "a ship officer's cabin" (Berger and Mohr, 2016, p. 54). Sassall's image of a doctor, as Berger puts it, is "A man who was all-knowing but looking haggard" (Berger and Mohr, 2016, p. 57). Berger explains this image through references to Conrad and quotations from his novels, The Nigger of the Narcissus and Typhoon. Berger states Sassall "constructed his ideal of responsibility" on Conrad's Master Mariners, seeing himself "as a life-saver", "serv"ing community (Berger and Mohr, 2016, p. 58). However, Sassall's notion of the doctor's imagination changes when he becomes a more experienced and older doctor in that he realizes the importance of his patients' imagination, which he considers equally valuable. Thus, his idea of imagination moves from the personal to the communal or collective. Sassall begins "to observe himself and others" (Berger and Mohr, 2016, p. 61). Berger says,

$\mathrm{He}$ [Sassall] began to take a different view of the meaning of the term crisis. He began to realize that the way Conrad's Master Mariners came to terms with their imagination- denying it any expression but projecting it all on to the sea which they then faced as though it were simultaneously their personal justification and their personal enemy- was not suitable for a doctor in his position. He had done just that- using illness and medical dangers as they used the sea. He began to realize that he must face his imagination, even explore it. It must no longer lead always to the 'unimaginable', as it had with the Master Mariners contemplating the possible fury of the elements- or, as in his case, to his contemplating only fights within the jaws of death itself. [...] He began to realize that imagination had to be lived with on every level: his own imagination first- because otherwise this could distort his observation- and then the imagination of his patients (Berger and Mohr, 2016, p. 60).

The relationship between the doctor and the patient is a dialectical one, as the case of Sassall suggests, in that both have to connect with the other. In such a relationship, the doctor recognizes the uniqueness of the patient while the patient realizes that s/he is not an exception as s/he notices some parts of his/her own personality reflected in the doctor:

This can be achieved by the doctor presenting himself to the patient as a comparable man. It demands from the doctor a true imaginative effort and precise self-knowledge. The patient must be given the 
chance to recognize, despite his aggravated self-consciousness, aspects of himself in the doctor, but in such a way that the doctor seems to be Everyman. [...] He [The patient] is no longer an exception. He can be recognized. And this is the prerequisite for cure or adaptation. (Berger and Mohr, 2016, p. 78)

The idea of empathy, social/human responsibility or "the desire to be universal" in Berger's view on Sassall's personality and practise, means proliferating oneself into countless others as "he 'becomes' each patient" (Berger and Mohr, 2016, p. 79). As the healer becomes a universal man, through a sense of fraternity, he also cures himself/herself when s/he cures one: "He [Sassall] cures others to cure himself" (Berger and Mohr, 2016, p. 79).

Berger deals specifically with the culturally and economically deprived society, as Sassall's patients belong to an "economically depressed" region and to the forest. The Foresters are "suspicious, independent, tough, poorly educated, low church" (Berger and Mohr, 2016, p. 91). Sassall lives in a larger house of the village and drives a Land Rover for his practice, and another car for his private use. His children go to the local grammar school. He is seen as a gentleman by the Foresters. Sassall, Berger says, "leads almost no social life of his own- except in the village with the villagers. It is when he is talking with his few middleclass neighbours that one is most aware of his own class background" (Berger and Mohr, 2016, p. 91). Berger relates the inarticulacy of the English working and middle classes to cultural destitution:

The inarticulateness of the English is the subject of many jokes and is often explained in terms of puritanism, shyness as a national characteristic, etc. This tends to obscure a more serious development. There are large sections of the English working and middle class who are inarticulate as the result of wholesale cultural deprivation. They are deprived of the means of translating what they know into thoughts which they can think. [...] The culturally deprived have far fewer ways of recognizing themselves. A great deal of their experience -especially emotional and introspective experience- has to remain unnamed for them. (Berger and Mohr, 2016, pp. 100-1)

The doctor/healer, in Berger's outlook, functions as the recorder of the history of the community, "the clerk of the records" (Berger and Mohr, 2016, p. 113). He is the "memory", "witness", "representative" and "self-consciousness" of society (Berger and Mohr, 2016, p. 111). Thus, Sassall is the "clerk" of history and culture of the villagers' and foresters'. In other words, the doctor mirrors and represents society as such:

He is the objective witness of their lives. [...] He is in no way a final arbiter. That is why I chose the rather humble word clerk: the clerk of their records. [...] He is not the representative of an all-knowing, all-powerful being. He is their own representative. [...] He keeps the records so that, from time to time, they can consult them themselves. [...] He represents them, becomes their objective (as opposed to subjective) memory, because he represents their lost possibility of understanding and relating to the outside world, and because he also represents some of what they know but cannot think. (Berger and Mohr, 2016, p. 111)

Berger's interest in history, historical consciousness, history-writing and recovery of history is integral to his work. Regarding this, Harvey Kaye argues "[W]here one does find a serious consideration of the need to recover history and reconstruct historical consciousness is in the work of John Berger" (Kaye, 1983, p. 44). Harvey's argument accounts for Berger's use of the metaphor of the doctor as a redeemer of humanity and chronicler of history. Kaye argues "mystification and cultural alienation" impedes historical consciousness (1983, p. 44) and refers to Berger's A Fortunate Man as an example of cultural /historical amnesia through inarticulacy and cultural deprivation (1983, p. 45).

Martyn Hudson examines Berger's works with a view to their relationship with Marxist history-writing, the dead and the past. Emphasizing the "ethical imperative to describe" (Hudson, 2000, p. 262) tradition, the past and the dead, Hudson argues Berger expresses the inarticulate, unsaid and unsayable through mediating between "the peasantry and the intelli- 
gentsia, the cosmopolitan and the provincial and the living and the dead. This radical act of translation means that he performs the task, as he once said of someone else, of "clerk of the foresters records"” (2000, p. 262).

The concepts of healing and health are socially/culturally constructed as Berger's text manifests. Berger criticizes the lack of historical foundation in his culture as he thinks the social/historical aspects of illness are ignored by society: "With the fatal a-historical basis of our culture, we tend to overlook or ignore the historical content of neuroses or mental illness" (Berger and Mohr, 2016, p. 145). The doctor's dilemma, hence, reflects society's sickness as illness is socially produced as well. Sassall's depression Berger thinks, also reflects the "neuroses", "depressions" and "illness" of the community:

From time to time Sassall becomes deeply depressed. The depression may last one, two or three months. $\mathrm{He}$ is not sure of the reason for these depressions. Extreme examples in the distant past are sometimes admitted. One grants that there was a connection in the fourteenth century between the outbreaks of St Vitus's Dance and the suffering caused by the Hundred Years' War and the Plague. [...] Vulnerability may have its own private causes, but it often reveals concisely what is wounding and damaging on a much larger scale (Berger and Mohr, 2016, pp. 145-146).

The doctor's value, for Berger, should be measured in terms of his/her humanity. Berger raises some questions concerning these issues and concludes that the value of a doctor or healing cannot be determined in the absence of a human society. He expresses the dual aspect of the doctor through the contrast between a technician and an artist in that Sassall feels responsible for his patients which resembles the artist's social responsibility: "Like an artist or like anybody else who believes that his work justifies his life, Sassall - by our society's miserable standards - is a fortunate man" (Berger and Mohr, 2016, p. 148). Berger criticizes his contemporary society on human grounds, as he believes they lack the necessary assets to acknowledge the worth of human life:

Then let us ask: What is the social value of a pain eased? What is the value of a life saved? [...] Should a doctor be judged professionally- by the consistent level of his professional skill? This would seem to make sense in the case of a surgeon, because his tasks, however complex, are limited. [...] It would be very much more difficult to judge a doctor like Sassall. [...] Let us assume that the consistent level of Sassall's performance as a doctor can be measured as a technique. He can then be graded as a technician. [...]

But could this satisfy us? The value of his capacity rather than the value of what he achieved?

It is true that my questions cannot be answered satisfactorily. But I was asking them to try to lead you to the point of realizing that we in our society do not know how to acknowledge, to measure the contribution of an ordinary working doctor. (Berger and Mohr, 2016, p. 165)

In Berger's view, the criteria for a healthy individual or society as well as the measure of the assessment of sickness in both individual and social terms are bound up with social relations and structures and the idea of humanism. In the conclusion of the book, quoting Gramsci, Berger asks "Is humanity as a reality and as an idea a point of departure or a point of arrival?" (Berger and Mohr, 2016, p. 167). Then, he addresses the same question to the reader once more, without the quotation marks. Berger emphasizes the necessity for action to be able to acknowledge the worth of a human life or a healthy life, which he thinks, can only be achieved through the production of a human society:

Is humanity as a reality and as an idea a point of departure or a point of arrival?

I do not claim to know what a human life is worth - the question cannot be answered by word but only by action, by the creation of a more human society.

All that I do know is that our present society wastes and, by the slow draining process of enforced hypocrisy, empties most of the lives which it does not destroy: and that, within its own terms, a doctor 
who has surpassed the stage of selling cures, either directly to the patient or through the agency of a state service, is unassessable. (Berger and Mohr, 2016, p.168)

Berger's critique of the post-war British society, reveals the ailment he identifies as being "without a scale of standards for judging or assessing one another" (Berger and Mohr, 2016, p. 163). Berger maintains that after the Second World War, the British were deprived of the power to make choices, as political choices were officially made on their behalf (Berger and Mohr, 2016, p. 163). The lack of commitment to and the failure to make choices, as Berger states, can be observed in social issues including "racial equality, the right to national ad economic independence, the ending of class exploitation, the struggle for freedom (and survival) in a police state, the abolition of famine" (Berger and Mohr, 2016, p. 163).

George Szanto explores the functions of "oppositional” perspectives in Berger's work, which depict a "complex" as well as "distorted" reality (Szanto, 1978, p. 364). Szanto argues "In its few moments of humanism and socialism he [Berger] finds in the world the possibilities for what, generally looking and seeing, is not" (Szanto, 1978, p. 364). Szanto also refers to the "social dialectics art plays" and "economic roles of social beings" as reflected in middle class life in A Fortunate Man (Szanto, 1978, p. 364).

The doctor's depression, here, is a reflection of a communal sickness or depression as well. The doctor's distress, Berger thinks, results from the incongruity between "the general expectations of his patients and his own" (Berger and Mohr, 2016, p. 142). Berger believes the doctor's effort to treat the whole personality of a patient culminates in the "bitter paradox" (Berger and Mohr, 2016, p. 142) in that the closer he examines each patient, the closer he comes to the fact of his patients' being underprivileged and unfortunate in social terms, for Sassall "knows that the foresters are in almost all respects unfortunate compared to what they could be-given better education, better social services, better employment, better cultural opportunities" (Berger and Mohr, 2016, p. 137).

The healer's relationship with the patients and society as Sassall's example demonstrates is manifest in the fourth story or case in the book. The story concerns Sassall's examination of one of his patients, who is a sixteen-year-old girl. The girl "was crying when she came into the surgery" (Berger and Mohr, 2016, p. 37). Sassall's attitude to his patient proves congenial, as he asks her the reason for her misery. It is further revealed that it was Sassall who delivered the girl as a baby, which adds to the fraternity between the doctor and the patient. After examining the girl medically and through asking questions about her physical health, Sassall asks her personal questions regarding her parents, her job, her education, and her prospects in order to help her to recover from her misery. He realizes that her discontent results from her dissatisfaction with her present position and her desire for a better one. He also tries to help her to receive the necessary training for the job she desires (Berger and Mohr, 2016, p. 39). The conversation between Sassall and his patient displays not only Sassall's empathy with his patient but also emphasizes his anguish because of the deprivation of his patients and their misery, as Berger states the girl examined by Sassall "is nubile in everything except her education and her chances" (Berger and Mohr, 2016, p. 38). The story, therefore manifests the dual aspect of the figure of the healer as both a Promethean hero who saves humanity and a tragic figure who suffers for humanity.

Anguish is a major form of illness Berger detects in contemporary society. Sassall and his patients suffer from the feeling of anguish. Berger's conception of anguish can be explained by referring to Sartre. Making a choice, according to Sartre, has universal consequences in that the choice concerns not only the individual but humanity. Thus, one's freedom or will impacts on the universal one. In other words, to Sartre, each authentic choice manifests universality or humanity (Sartre, 2007, pp. 17-72). In his 1945 lecture entitled "Existentialism 
Is a Humanism", Sartre defends his theory of existentialism and emphasizes the human responsibility of existence and of the individual will: "Our responsibility is thus much greater than we might have supposed, because it concerns all mankind” (2007, p. 24). As Sartre puts it,

The word "subjectivism" has two possible interpretations, and our opponents play with both of them, at our expense. Subjectivism means, on the one hand, the freedom of the individual subject to choose what he will be, and, on the other, man's inability to transcend human subjectivity. The fundamental meaning of existentialism resides in the latter. When we say that man chooses himself, not only do we mean that each of us must choose himself, but also that in choosing himself, he is choosing for all men. (2007, pp. 23-24)

The healer/doctor Sassall suffers from existential dilemma or anguish since he is aware that his choices, however limited, will influence his patients, community and humanity as well. Sassall resembles Sartre's universal humanist for he goes beyond and forgets himself to serve humanity, as Sartre states "man is always outside of himself, and it is in projecting and losing himself beyond himself that man is realized; and, on the other hand, it is in pursuing transcendent goals that he is able to exist" (Sartre, 2007, p. 52). Similarly, as Berger puts it, Sassall's "aim is the Universal Man" (Berger and Mohr, 2016, p. 144). As a universal humanist, Sassall, the doctor, expands himself into multiple selves through "his imaginative 'proliferation' of himself in becoming one patient after another" (Berger and Mohr, 2016, p. 144).

The anguish Berger mentions and Sassall as well as society faces and his emphasis on humanism can be compared to Antoine Roquentin's existential dilemma and fear in Nausea. Sassall's predicament involving the dual roles of the doctor as a scientist and a humanist is similar to Roquentin's dilemma:

I shall lean against a wall and as they go by I shall shout to them: 'What have you done with your science? What have you done with your humanism? Where is your dignity as a thinking reed?' I shan't be afraid-or at least no more than I am now. Won't it still be existence, variations on existence? All those eyes which will slowly eat up a face - no doubt they will be superfluous, but no more superfluous than the first two. Existence is what I am afraid of. (Sartre, 2000, p. 227)

Sassall's recurrent depression reveals the anguish suffered by his patients. Berger refers to Van Gogh as an example of the social anguish observed in a specific era which is manifest in the artist's inner turmoil: "But do we appreciate, for example, how much Van Gogh's inner conflicts reflected the moral contradictions of the late nineteenth century?" (Berger and Mohr, 2016, p. 146). "Sassall's depressions are maintained", Berger says, by "the suffering of his patients and his own sense of inadequacy" (Berger and Mohr, 2016, p. 146). Sassall's inner conflict can be observed in his sense of inadequacy, which "is larger than professional" as he persistently asks himself "Do his patients deserve the lives they lead, or do they deserve better? Are they what they could be or are they suffering continual diminution?" (Berger and Mohr, 2016, p. 135).

The anguish Sassall's patients face is "the anguish of dying, of loss, of fear, of loneliness, of being desperately beside oneself, of the sense of futility" (Berger and Mohr, 2016, p. 115) rather than a physical kind of anguish. "What is the effect of facing, trying to understand, hoping to overcome the extreme anguish of other persons five or six times a week?" Berger asks (Berger and Mohr, 2016, p. 115). The question reveals the magnitude of the problems and risks faced by doctors, including Sassall, while practising their profession, mainly the diseases they may develop as a result. The Faustian dangers awaiting the healer, as it is embodied in this essay is the depression or paranoia Sassall develops as a result of the incongruity between "his developed sensibility and the underprivileged life of his chosen patients" (Berger and Mohr, 2016, p. 147). As Sassall feels guilty for his patients' plight, he becomes 
extremely "susceptible to the suffering of others" (Berger and Mohr, 2016, p. 147). The suffering of Sassall's patients, also reveals "the comparative emptiness of his own life" (Berger and Mohr, 2016, p. 147). Sassall's feeling of sickness may result from the sense of inability to come to terms with and cure his existence and contemporary society including the life of his patients. The Sartrean anguish suffered by the doctor as well as the patients can also be defined as the contingency of human existence, and the obligation to make choices where all is arbitrary and meaningless. Berger quotes Sartre's Nausea to account for the feeling of anguish or nausea:

But no necessary being can explain existence: contingency is not an illusion, an appearance which can be dissipated; it is absolute, and consequently perfect gratutiousness. Everything is gratuitous, that park, this town, and myself. When you realize that, it turns your stomach over and everything starts floating about, as it did the other evening at the Rendezvous Des Cheminots; that is the Nausea ... (Berger and Mohr, 2016, p. 125)

The dangers faced by the healer can also be explained by referring to the concept of "the wounded healer", which signifies "the inner 'woundedness' of a healer, the healer's own suffering and vulnerability which have been said to contribute crucially to the capacity to heal" (Jackson, 2001, p. 2). As Stanley Jackson puts it, the healer may consult his/her own "sufferings" "as bases for understanding, appreciating, and empathizing with the wounds and sufferings of others" (Jackson, 2001, p. 36). In this respect, John Sassall can be regarded as a "wounded healer", whose own vulnerability or depression complements and aids in curing others.

In conclusion, it is observed that the idea of healing in A Fortunate Man is connected with the concept of universal humanism. Accordingly, the value of a healer as well as the value of a work of art or an author are determined through the value of humanity and human life. It is revealed that the personal and the public aspects of sickness are interrelated as the individual's illness reflects society's ailment. Through the metaphor of the doctor, Berger criticizes the lack of humanity in contemporary society, which fails to acknowledge the value of an individual, as well as demonstrating the doctor's dilemma which reflects the society s/he represents and the anguish suffered by the individuals.

\section{Genişletilmiş Öz}

İyileş(tir)me düşüncesi, John Berger'in makalesi/anlatısı ve Jean Mohr'un fotoğraflarından oluşan A Fortunate Man: The Story of a Country Doctor (Talihli bir Adam: Bir Taşra Doktorunun Öyküsü) adlı kitapta, bireysel açıdan ele alındığı gibi esas olarak toplumsal ve hümanist bakışla ortaya konur. Kitapta taşra doktoru olan John Sassall'ın yaşam öyküsü anlatılırken doktor figürünün toplumsal sağlık ve evrensel hümanizmayı ifade eden bir metafor olarak kullanıldığı görülür. Dolayısıyla iyileştirici ya da iyileşmenin değeri, toplumun değeri ve insanlık değeriyle koşuttur. Bu makalenin amacı A Fortunate Man'de iyileş$\mathrm{me} / \mathrm{sağlık} \mathrm{kavramını} \mathrm{ve} \mathrm{iyileştirici/sağaltıcı} \mathrm{figürünü} \mathrm{esas} \mathrm{olarak} \mathrm{toplumsal} \mathrm{ve} \mathrm{insani} \mathrm{açılardan}$ incelemektir.

Kitapta, doktor ya da iyileştirici figürü "Evrensel İnsan" kavramıyla ifade edilir ve insanlığa karşı sorumlu olma ve bu doğrultuda bireysel ve evrensel seçimlerde bulunma düşüncesiyle irdelenir. Berger bu düşünceleri Sartre ve Gramsci gibi düşünürlerden yaptığ 1 alıntılarla da destekler. Dr Sassall'ın sahip olduğu "kardeşlik" duygusu metinde vurgulanan evrensel hümanizma kavramının en dikkat çekici örneklerindendir. Öyle ki, Dr Sassall'ın kardeşlik ve empati yoluyla kendi benliğini sayısız ötekiye dönüştürmesi onun hümanist bakışını göz önüne serer. Bu açıdan doktorun ya da iyileştiricinin yaşadığı varoluşsal endişe toplumsal endişenin (angst/anguish) göstergesidir. 
Sağlık kavramına bireysel bakıştan ziyade toplumsal açıdan yaklaşan metinde bireyin sağlığı ve refahının toplumsal başarı ve esenlikle orantılı olduğu ifade edilir. Bu yüzden, Dr Sassall'ın hastalarının sağlığı ait oldukları geri kalmış taşra yaşamıyla ilişkilidir ve bölge halkının ekonomik ve kültürel yoksunluğu onların sağlığını ya da refahını birincil olarak etkilemektedir. Doktorun toplumsal ișlevi ya da toplumu yansıtmadaki rolü Berger'in toplumsal hafızayı vurguladığı toplumun "kayıtlarının katibi" ya da toplumun şahidi ifadesiyle gösterilir.

Berger'in düşüncesinde "hikayeciler" (storytellers) okurun ve insanlığın kurtarıcısıdır. Bir başka deyişle, hikayeciler yabancı ve tekinsiz olanı aşina kılarak insanlığı bilinmeyen, söylenilemeyen ve saçmaya karşı hazırlar. Hikayeciler doktor gibi kurtarıcı rolüne sahiptir; okuru bilinmeyene karşı hazırlar. Fakat aynı zamanda hikayeci ya da doktor bilinmeyenle işbirliği içindedir. Metinde doktor-hikayeci benzetmesi aracılığıyla Sassall'ın hastalarına bilinmeyenin kapısını araladığı düşüncesi yazılı ve görsel olarak ifade edilir. Dahası Berger'in anlatımında kurmaca hikayeyle tıbbi vaka birbirinin içine girer; doktorun biyografisiyle karşılaştığı tıbbi vakalar öykülenir. Berger'in yaklaşımında, doktor yazarla benzer role sahiptir.

Kitapta hastalık kavramı genel anlamının yanı sıra zihinsel ya da psikolojik sağlıkla da ilişkilendirilir; bireylerde görülen rahatsızlıkların toplumsal bir sıkıntıyla ilgili olabileceği görüşü ortaya konur. Berger'e göre bireyin yaşadığı endişe ve buhran toplumsal ölçekte eşzamanlı oluşan ve yazar, sanatçı ve doktor gibi toplumun farklı kesimlerinden bireylerin de yaşamına yansıyan toplumsal endişe ve rahatsızlığı yansıtmaktadır. Yazar, Sassall'ın yaşadığ 1 duygusal çöküntüyü toplumsal bir hadise olarak değerlendirir.

Berger, Sassall'ın yaşadığı bölgeden yola çıkarak İkinci Dünya Savaşı sonrası Britanya'sını eleştirir. Dr Sassall'ın sorumlu olduğu taşra halkının içinde bulunduğu yoksullukla kültürel ve ekonomik yoksunluğu Berger dönemin Britanya'sında eksik olduğunu düşündüğü toplumsal sorumluluk, kayıtsızlık, eşitsizlik ve seçim yapma yetisinden yoksun olma gibi hususlarla ilişkilendirir. Berger'e göre insan değerini bilmeyen bir toplum, doktorun da değerini bilmez. Dolayısıyla ancak insanca bir toplum yaratarak sağlıklı bir toplum oluşturulabilir, ya da hümanist bir çerçevede sağlıklı bir toplum oluşur.

Doktor-hasta ilişkisi metinde diyalektik olarak ele alınır. Berger'e göre doktorun hastalarının her birini tek ve benzersiz olarak görmesi gerekirken hastaların da doktoru kendilerine benzer özelliklere sahip olan bir kişi olarak görmelerinin gereği ifade edilir. Bir başka deyişle, Berger'in düşüncesinde doctor-hasta ilişkisi, Sassall'ın durumunda da görüldügü gibi "evrensel insan" perspektifinde gerçekleşmelidir.

Doktor figürü metinde gemi kaptanı metaforuyla da pekiştirilir. Dr Sassall üzerinde büyük etkisi olan yazar Joseph Conrad'in yapıtlarındaki gemi kaptanlarına yapılan göndermeler yoluyla doktorda ve kaptanda olması gereken sorumluluk duygusuyla evrensel hümanizma ve kardeşlik düşünceleri koşut olarak ele alınır. Sassall'da görülen topluma ve insanlığa hizmet bilinci gemi kaptanı benzetmesiyle iyileştiricinin kurtarıcı işlevine dikkat çekilirken aynı zamanda Conrad'ın kaptanlarında görülen tehlike ve zorluklara da işaret edilir.

İyileştirici figürü kitapta doktor/hasta, derman/yara ikili zıtlıklarını bünyesinde eşzamanlı olarak bulunduran bölünmüş bir benlik olarak ortaya konur. John Sassall'ın temsil ettiği iyileştirici, "Yaralı sağaltıcı" rolüne bürünür. Bu açıdan, iyileştirici/doktor, bir yandan kendi yaralarından ötürü hastalarıyla kolaylıkla empati kurup çare olurken diğer bir yandan da hastaları için yaptığı fedakarlıkla kendinden ödün vermekte ve sağlığını yitirebilmektedir. John Berger bu bağlamda doktorun ya da sağaltıcının karşı karşıya olduğu Faustvari tehlikeli durumları Dr Sassall'ın yaşam öyküsü aracılığıyla dile getirir. Nitekim, Sassall ya da doktor 
empati ve kardeşlik duygularıyla hastalarına derman olmaya çalışırken, onların yaşam şartlarını iyileştirememenin neden olduğu yetersizlik ve endişe duygusu kendi sağlığı için bir tehdit oluşturur.

Anlatıyla fotoğrafın birbirini bütünlediği metinde özellikle yakın çekim tekniğinin kullanılmasıyla başlıca düşüncelerin desteklendiği gözlemlenir. Nitekim insan odaklı bir toplum düşüncesinin önemi yakın çekim fotoğraflar aracılığıyla da vurgulanır. Bu fotoğraflarda doktorun hastaya gösterdiği empati, hastanın doktora duyduğu kardeşlik ve güvenin yanı sıra doktorun ve hastaların ayrı ayrı fotoğraflarla yaşadıkları coğrafyaya dair fotoğraflar insanın öne çıktığı hümanist bir anlayışla betimlenir.

Sonuç olarak, A Fortunate Man'de doktor/sağaltıcı metaforuyla ve özellikle doktorun yaşadığı ikilem ve rahatsızlıkla hastaların ve toplumun endişe ve sıkıntıları aracılığıyla evrensel hümanizma düşüncesinin önemi vurgulanır ve çağdaş toplumda bu açıdan görülen eksiklik eleştirilir.

\section{References}

Berger, J., \& Mohr J. (2016). A fortunate man: The story of a country doctor. Edinburgh: Canongate Books Ltd.

Berger, J., \& Sontag S. (1983). To tell a story. Voices. Retrieved 12 September 2019 from: https://photographytheoryintopractice.wordpress.com/2017/02/15/john-berger-andsusan-sontag-telling-stories/.

Francis, G. (2016). Introduction. In A fortunate man: The story of a country doctor. Edinburgh: Canongate Books Ltd. 9-15.

Hudson, M. (2000). The clerk of the foresters records: John Berger, the dead, and the writing of history. Rethinking History, 4(3). 261-279. doi.org/10.1080/136425200456967.

Jackson, S. (2001). Presidential address: The wounded healer. Bulletin of the History of Medicine, 75(1), 1-36. Retrieved 15 January 2020 from: www.jstor.org/stable/44445554.

Kaye, H. J. (1983). Historical consciousness and storytelling: John Berger's fiction. Mosaic: An Interdisciplinary Critical Journal, 16 (4). 43-57. Retrieved 09 November 2018 from: https://www.jstor.org/stable/24777713.

Robbins, B. (1982). Feeling global: Experience and John Berger. Boundary 2, 11 (1/2), 291308. doi: $10.2307 / 303030$

Sartre, J. P. (2000). Nausea. (R. Baldick, Trans.). London: Penguin Books.

Sartre, J. P. (2007). Existentialism is a humanism. Macomber, C. (Ed.). (J. Kulka, Trans.). New Haven and London: Yale UP.

Sontag, S. (1978). Illness as metaphor. Toronto: McGraw-Hill Ryerson Ltd.

Szanto, G. (1978). Oppositional way-signs: some passages within John Berger's historymaking, history-unravelling experiment. College English, 40(4). 364-378. doi:10.2307/376255 